\title{
Anticancer effects of Annona muricata with its acetogenins as bioactive compound
}

\author{
Banerjee $\mathrm{A}^{1 *}$, Das $\mathrm{D}^{2}$, Maji BK${ }^{1}$ and Mukherjee $\mathrm{S}^{1}$ \\ ${ }^{1}$ Department of Physiology, Serampore College, Serampore, Hooghly, West Bengal, \\ India \\ ${ }^{2}$ Bengal Institute of Pharmaceutical Sciences (BIPS), Kalyani, Nadia, West Bengal, India
}

\section{Review Article}

Volume 2 Issue 1

Received Date: February 21, 2018

Published Date: March 05, 2018

*Corresponding author: Arnab Banerjee, Research scholar, Department of Physiology, Serampore College, Serampore, Hooghly-712201, West Bengal, India, Tel: +91-9836944762; E-mail: arnab.world10@gmail.com

\section{Abstract}

Annona muricata, commonly known as soursop, graviola and guanabana, is a member of the Annonaceae family and is mostly distributed in tropical and subtropical regions of the world. In the absence of an effective treatment in modern medicine, efforts are being made to find suitable herbal drugs. The use of natural product medicines has emerged from traditional to modern therapy in order to increase the quality of health worldwide. The soursop is a traditional medicinal plant which is empirically by the people of Indonesia is used for anti-inflammatory and anti-tumor. A wide array of ethnomedicinal activities is contributed to different parts of Annona muricata, and indigenous communities in Africa and South America extensively use this plant in their folk medicine. Soursop has anticancer, anticonvulsant, anti-arthritic, antiparasitic, antimalarial, hepatoprotective and antidiabetic activities. Phytochemical studies reveal that annonaceous acetogenins are the major constituents of A. muricata. A wide range of chemical compounds including Alkaloids (acetogenins), lipids, isoquinoline, lactones, Annomuricatina (protein), Bullatacin, Muricoreacin etc. have been isolated from this species. The annonaceous acetogenins are selectively toxic to cancer cells, including multi-drug-resistant cancer cell lines. So, the review work mainly focused on the anticancer activity of Annona muricata, here is the initiation for the future anticancer drug from the natural source.

Keywords: Annona muricata; Acetogenins

Abbreviations: PC: Pancreatic Cancer; WHO: World Health Organization; ROS: Reactive Oxygen Species

\section{Introduction}

Home grown pharmaceutical goes regarding because the delegate of the foremost important fields of customary medication, everyplace throughout the planet. The review on the restorative plants is basic to advance the most effective potential utilization of natural prescription with a particular finish goal to come to a decision their potential as a hotspot for the new medications. Herbal drugs acts because the representative of the foremost vital fields of ancient drugs, everywhere the planet. The study on the healthful 
plants is important to market the right use of flavored drugs so as to work out their potential as a supply for the new medication. Consistent with world health organization (WHO), larger than eightieth of the entire world's population depends on the normal medicines so as to satisfy their primary health care wants. Annona muricata L. is commonly known as soursop, guanábana, graviola, sirsak, zuurzak, coracao-da-índia, guyabano or corossol. The soursop is come from the Caribbean and rain forest of northern South America, including Amazon. In the USA it has limited production in Florida and it is known as a native fruit from the West Indies, Central America, down to Brazil and it is a common fruit in tropical Asia. Now, soursop has spread throughout the humid tropics so it is also grown in Southeast Asia included Malaysia and Indonesia. It has also other local names like thorny custard apple, cherimoya and brazilian pawpaw. In other various languages, this fruit is known as: Gishta (Ethiopia), guanabana (Spanish), corossol (French), aluguntugui (Ghana), sorsaka (Papiamento), adunu (Acholi), guyabano, guanavana, durian benggala, nangkablanda, sirsak, toge-banreisi, nangkalonda, zuurzak, Brazilian Paw Paw, Corossol, Corossol epineux, Corossolier, Durian Benggala, Guanabana, Guanavana, Nangka Blanda, Nangka Londa, Soursop, Sour Sop, TogeBanreisi. guanaba, épineux, huanaba, toge-banreisi, durian benggala and cachiman épineux. In India, it is less known as shul-ram-fal and hanuman fal, and as mullaatha in Malayalam, whereas in Harar (Ethiopia) in Harari language known for centuries as Amba Shoukh (Thorny Mango or Thorny Fruit). Soursop could be a member of the family of Custard apple trees referred to as Annonaceae. Soursop could be a tiny, abundant branched, perennial, upright evergreen tree, $3-8 \mathrm{~m}$ long with giant, glossy, dark inexperienced leaves and rounded having chromatic hairless branchlets. Leaves area unit biseriate, shortly petiolate, and pale inexperienced to bright inexperienced, rectangular-obovate or oblong elliptic, 6$18 \mathrm{~cm}$ by $3-7 \mathrm{~cm}$ wide, shiny leaves and laurel-like with acuminate apex and unsubdivided or acute base. Flowers area unit regular, green to yellowish green (to yellow on a yellow fruited variety), on short axillary, 1-2 patterned branchlets. Flower has 3 dark inexperienced, ovate deltoid, leathered sepals that area unit pubescent and persistent; six loosely ovate, coriaceous, and typically inexperienced to after yellowish-green, tomentose, heartshaped base petals; Petals all ovate, inner smaller however each whorls valvate; having varied stamens in rows round the gynoecium; varied ovary, pubescent with designs formed like soft prickles. It produces outsized, cordate, green groceries that's $15-20 \mathrm{~cm}$ in diameter and beset with soft spines with a skinny, inexperienced or yellow or orange, inedible, areoles distinct, leathered rind, with white flesh within. The fruits sometimes slightly acidic style once ripe, that's why it's referred to as soursop. Seeds area unit varied, obovoid and twodimensional, dark brown to black, hairless and shiny, embedded in firm, white, fleshy, acid-sweet, juicy pulp. In several countries it's been used as ancient drugs. The leaves, fruit, seeds, bark, root and stem area unit used for ancient remedies in several countries [1].

Annonaceous acetogeneins area unit powerful photochemical found within the Graviola plant (Annona muricata), that area unit found solely in Annonaceae family. These chemicals normally are documented with antitumorous, antiparasitic, insecticidal, and antimicrobial activities [2]. These chemicals were less toxic; on considering the growth activity and its relative toxicity, they may be used as a cause develops a possible antineoplastic agent [3]. These acetogeneins area unit excellent inhibitors of accelerator process that area unit found solely within the membranes of cancerous tumor cells. The inhibitor activity is additionally associated with their ability to quench reactive element species like undergarment molecular element and peroxyl radicals therefore acting as deactivators of excited molecules or as chain breaking agents [4]. Graviola contains several chemicals that will move against cancer [5], likewise as disease-causing agents like microorganism, viruses, and parasites. Three separate analysis teams have confirmed that these chemicals have vital antitumorous properties and selective toxicity against numerous kinds of cancer cells while not harming healthy cells. There is an issue concerning safety identification of Graviola. It will kill nerve cells within the brain and different elements of the body. It should cause movement disorders. It is not recommended to use Graviola throughout maternity and infant feeding. The leaves area unit lance like with shiny and dark inexperienced in color had been historically wont to treat headaches, high blood pressure, cough, asthma attack and used as medicament, sedative and nervine for heart disease. Previous reports concerning this plant species from completely different countries have incontestable that the leaf, bark, root, stem, and fruit seed extracts of soursop tree area unit anti-bacterial. Soursop tree could be a potent antineoplastic plant of Annonaceae family. Leaf extracts of $A$. muricata posses vital antineoplastic potentials in human cancerous cells. Plant phenolics area unit a serious cluster of compounds that act as primary antioxidants or radical scavengers [6]. Fruit extracts show antiviral, antinociceptive, medicament and antihyperglycemic properties. It is conjointly effective against multidrug resistant neoplastic cell line [5]. 
The seeds and leaves of those species were found to contain over fifty mono-THF acetogenins. A number of the key intermediates that area unit concerned within the synthesis of those acetogenins has been isolated from this species recently and were named as epomuricenins- $A$ and $\mathrm{B}$, montecristin, cohibins- $\mathrm{A}$ and $\mathrm{B}$, muridienins- 1 and a couple of, muridienins- 3 and four, muricadienin and chatenaytrienins-1, two and three and conjointly a brand new compound referred to as sabadelin which could be a propagation precursor of cis-panatellin11.The leaf, stem, root and seed extract of soursop tree have the bactericide activity against varied pathogens [7]. The leaves, roots and seeds of graviola incontestible insecticidal properties, with these seeds demonstrating robust insecticidal activity [8]. The photochemical gift in soursop tree area unit alkaloids, Flavonoids, carbohydrates, viscus glycosides, saponins, tannins, phytosterol, terpenoids and proteins [9]. soursop tree acts as ideal antidiabetic drug since it posses each symptom and inhibitor properties with none adverse effects [10]. The leaves of soursop tree act as molluscicidal and Anti-parasitical agents [11]. Annona muricata used to cure inflammatory conditions like Flu and cough. People in the older days used to mix Annona muricata tree extract from the roots, leaves and stem to make tea and other solution which was given to people suffering from various illnesses. Soursop tree extract resolution was applied on the body to treat rheumatism, inflammatory disease and the other pain in joints. Soursop tree oils are often extracted from its leaves. The leaves are often crushed at the side of raw fruit from the plant and mixed with vegetable oil. The oil is often wont to treat numerous skin disorders like rashes, boils and sores [12]. Many early studies incontestable that the bark likewise because the leaves had hypotensive, medicament, medicine, dilator, smoothmuscle relaxant, and cardiode pressant activities in animals [13,14]. Researchers verified graviola leaf's hypotensive properties in rats once more in 1991 [15]. Many studies over the years have incontestable that leaf, bark, root, stem, and seed extracts of graviola area unit bactericide in vitro against varied pathogens which the bark has antifungal properties [16-19]. Graviola seeds incontestible active antiparasitic properties during a 1991 study, that valid its long standing ancient use and a leaf extract showed to move against protozoal infection in two different studies [20,3]. The leaves, root, and seeds of graviola incontestible insecticidal properties, with the seeds demonstrating robust insecticidal activity in associate degree early 1940 study [21]. During a 1997 clinical study, novel alkaloids found in graviola fruit exhibited antidepressive effects in animals [22]. The current review study is, therefore, undertaken to judge and a promise to our individuals for the initiation of future anticancer drug from this gift of nature.

\section{Photochemistry}

There are various phytoconstituents found in different parts of Annona muricata plant with the presence of major minerals like $\mathrm{K}, \mathrm{Ca}, \mathrm{Na}, \mathrm{Cu}, \mathrm{Fe}$ and $\mathrm{Mg}$. So, it can be hypothesized that this plant can help to provide essential nutrients and elements to the human being.

Following are some phytoconstituents found from different parts of $A$. muricata plant
a) Alkaloids
b) Megastigmanes
c) Flavonol triglycosides
d) Phenolics
e) Cyclopeptides
f) Essential oils

A. muricata have been shown to be a generally high source of annonaceous acetogenin compounds (AGEs). AGEs are primarily toxic against cancer cells and inhibitory effects against the mitochondrial complex I (mitochondrial NADH: ubiquinone oxidoreductase) [23].

\section{Ethnomedicinal uses of Graviola}

In tropical countries, almost all the vegetative parts of the Graviola plant are used in medicinal purpose. The vegetative parts are mostly bark, leaves, roots, fruit, and seeds.Specific plant parts have different medicinal uses. The fruit and fruit juice have anti helminthic and anti parasitic activities. The graviola fruit is used as anti pyretics also. And it is believed that it increases the lactation capacity of a lactating mother. Crushed seeds are used to kill lice. Tea prepared from bark, leaves and roots have sedative, anti spasmodic effects as declared by tropical ethnomedicine. In the Peruvian Andes, the graviola leaf tea is used to heal inflammation of mucous membrane. In the Peruvian Amazon graviola is used to treat diabetes Indigenous tribes in Guyana use its leaf and bark tea as a heart tonic. In Brazil, graviola leaf tea is used also to cure liver problems. The graviola leaf oil is mixed with olive oil and used externally for neuralgia, rheumatism, and arthritis pain. Similar uses are known in Jamaica, Haiti and West Indies [23].

\section{Anticancer activity}

Previous study showed that the alcohol extract of leaves of $A$. muricata causes cell death of the liver cancer cells in vitro through ER stress pathway. Ethanolic extracts of $A$. muricata leaves incontestable 
chemopreventive effects in an exceedingly model of skin nonmalignant tumour genesis, with complete inhibition of the growth development and vital increase in latent amount. A. muricata leaves indicated most grounded cytotoxic action against MCF-7 bosom illness cell line and it induced cell death in A549 cells through mitochondrialmediated pathway involving NF- $\kappa$ B. A. muricata methane series and commercial extracts incited mellow toxicity in carcinoma cell Capan-1, Norse deity cervical cancer cells, Vero cell line. Alcohol extract of leaves of A. muricata has cytotoxic activity in T47D carcinoma cell lines and may initiate cell death. Ethyl acetate fraction has the simplest efficiency of cytotoxic among alternative fractions against T47D carcinoma cell lines. Liquid leaf extract of $A$. muricata have antiproliferative activity of on the prostate, BPH-1 cells, and a few target genes and reduces prostate size, presumably through cell death. Annonaceous acetogenins, chemicals were less toxic; on considering the antitumor activity and its relative toxicity, they might be used as an anticancer agent [24]. Annonaceous acetogenins found only in the Annonaceae family kill malignant cells of 12 different types of cancer such as breast, ovarian, colon, prostate, liver, lung, pancreatic and lymphoma [25].

\section{Following are some anticancer activities of Annona muricata on different cancer cell lines}

In Huh-7 cell line Annona muricata showed a cytotoxic as well as apoptotic activity. Annona muricata leaves specifically reduce viability of hepatocellular carcinoma cells possibly through G0/G1 or S phase arrest or possibly via induction of sub-G0/G1 DNA fragmentation [24].

a) The Ethanolic extract from Annona muricata leaves induced necrosis of pancreatic cancer (PC) cells by inhibiting cellular metabolism. The presence of Annonaceous acetogenins in the extract was evident by the depletion of ATP production in PC cells. The results, thus suggest that the $A$. muricata leaves extract is able to suppress tumor initiation as well as tumor promotion even at lower dosage.

b) The acetogenins showed significantly selective in vitro cytotoxicities toward the human hepatoma cell lines HepG2 cell line.

c) Bioactivity-directed fractionation of the leaves of Annona muricata resulted in the isolation of annopentocins A (1), B (2), and C (3), and cis- and trans-annomuricin-D-ones $(4,5)$. Compound 1 was selectively cytotoxic to pancreatic carcinoma cells (PACA-2), and 2 and 3 were selectively cytotoxic to lung carcinoma cells (A-549); the mixture of 4 and 5 was selectively cytotoxic for the lung (A-549), colon (HT-29), and pancreatic (PACA-2) cell lines with potencies equal to or exceeding those of Adriamycin.
Bioactivity-directed fractionation of the seeds of Annona muricata L. (Annonaceae) resulted in the isolation of five new compounds: cis-annonacin (1), cisannonacin-10-one (2), cis-goniothalamicin (3), arianacin (4), and javoricin (5). Compound 1 was selectively cytotoxic to colon adenocarcinoma cells (HT-29) in which it was 10,000 times the potency of Adriamycin.

d) Bioactivity-directed fractionation of the leaves of Annona muricata L. (Annonaceae) resulted in the isolation of two new Annonaceous acetogenins, muricoreacin (1) and murihexocin C (2). Compounds 1 and 2 showed significant cytotoxicities among six human tumor cell lines with selectivities to the prostate adenocarcinoma (PC-3) and pancreatic carcinoma (PACA-2) cell lines.

e) Bioactivity-directed fractionation of the leaf extract of Annona muricata L. (Annonaceae) has resulted in the isolation of two new Annonaceous acetogenins, annomuricine (1) and muricapentocin (2). Compounds 1 and 2 showed significant cytotoxicities against six types of human tumors, with selectivities to the pancreatic carcinoma (PACA-2) and colon adenocarcinoma (HT-29) cell lines.

f) Components from the leaves of Annona muricata, three novel monotetrahydrofuran Annonaceous acetogenins, namely, annomutacin [1], (2,4-trans)- 10R-annonacinA-one [2], and (2,4-cis)-10R- annonacin-A-one [3], have been identified. Compound 1 and the mixture of compounds 2 and 3 showed selective cytotoxicities against the human A-549 lung tumor cell line.

g) The leaves of Annonamuricata have yielded two additional monotetrahydrofuran Annonaceous acetogenins, annomuricin C [1] and muricatocin C [2]. Compounds 1 and 2 showed cytotoxicities against the A-549 human lung and the MCF-7 human beast solid tumor cell lines.

h) Annona muricata L (Annonaceae) also showed chemopreventive effects in a two-stage model of skin papillomagenesis.

i) Cytotoxic potential of n-butanolic leaf extract of Annona muricata L. on WRL-68 (normal human hepatic cells), MDA-MB-435S (human breast carcinoma cells) and HaCaT (human immortalized keratinocyte cells) lines.

j) Annonaceous acetogenins are a new class of compounds that have been reported to have potent pesticidal, parasiticidal, anti-microbial, cell growth inhibitory activities. Treatment of MCF-7 and K-562 cells with organic and aqueous extracts resulted in nuclear condensation, DNA fragmentation, induction of reactive oxygen species (ROS) generation and reduced intracellular glutathione levels. Induction of apoptosis 
in MCF-7 and K-562 cells by both the extracts through oxidative stress [25].

\section{Conclusion}

Medicinal plants play a useful note in the development of modern therapeutic agents. The present study conclusively demonstrates that Annona muricata is a good source of various phytochemicals. On the basis of previous results, it can be concluded that the Annonaceous acetogeneins are powerful phytochemicals found in Annona muricata, offers protective effect against cancer. But, to elucidate the exact mechanism of this modulatory effect and to examine its potential therapeutic effects further studies are essential.

\section{Acknowledgement}

Authors are really grateful to Prof. Dhrubajyoti Chattopadhyay, Vice Chancellor of Amity University, Kolkata, for his continuous encouragement and valuable suggestions. We are thankful to Mr. Gaurab Banerjee, Mr. Abhishek Kantha, Mr. Aniruddha Sengupta and Ms. Piya Majumdar of Department of Physiology (UG \& PG), Serampore College for their technical help during this study.

\section{Conflicts of Interest}

The authors declare no conflict of interest.

\section{References}

1. Edwards S, Tadesse M, Demissew S, Hedberg I (2000) Flora of Ethiopia and Eritrea. The National Herbarium 2: 10 .

2. Keinan E, Sinha SC, Grynszpan F, Neogi P, Avedissian $\mathrm{H}$, et al. (1997-1998) Antibody-catalyzed organic and organometallic transformations and chemical libraries of Annonaceous acetogenins. The Skaggs Institute for Chemical Biology Scientific Report.

3. Wang LQ Min BS, Li Y, Nakamura N, Qin GW, et al. (2002) Annonaceous acetogenins from the leaves of Annona montana. Bioorg Med Chem 10(3): 561.

4. Scoppola A, Montecchi FR, Mezinger G, Lala A (2001) Urinary mevelonate excresion rate in type 2 diabetes: role of metabolic control. Artherosclerosis 156(2): 357.
5. Oberlies NH, Chang CJ, McLaughlin JL (1997) Structure-Activity Relationships of Diverse Annonaceous Acetogenins against Multidrug Resistant Human Mammary Adenocarcinoma (MCF7/Adr) Cells. Journal of Medicinal Chemistry 40(13): 2102-2106.

6. Polterait O (1997) Antioxidants and free-radical scavengers of Natural Origin. Current Org Chem 1(4): 415-440.

7. Sundarrao K, I Burrows, Kunduk M, Yi YD, Chung MH, et al. (1993) Preliminary screening of antibacterial and antitumor activities of Papua New Guinean native medicinal plants. Int. J. Pharmacog 31(1): 3-6.

8. Tattersfield F, Potter C (1940) The insecticidal properties of certain species of Annona and an Indian strain of Mundulea sericea (Supli). Ann Appl Biol 27(2): 262-273.

9. Vijayameena C, Subhashini G, Loganayagi M, Ramesh B (2013) Phytochemical screening and assessment of antibacterial activity for the bioactive compounds in Annona muricata. Int J Curr Microbiol App 2(1): 1-8.

10. Lenk SE, Bhat D, Blankeney W, Dunn WA (1992) Effects of streptozotocin-induced diabetes on rough endoplasmic reticulum and lysosomes of the rat liver. Am J Physiol 263(5): 856-862.

11. Bieber LW, de Luna JS, dos Santos AF, de Lima MRF, de Omena MC, et al. (2005) A study of the larvicidal and molluscicidal activities of some medicinal plants from northeast. B J of Ethnopharmacol 97: 199.

12. Padma P, Chansauria JPN, Khosa RL, Ray AK (2001) Effect of Annona muricata and Polyalthia cerasoides on brain neurotransmitters and enzyme monoamine oxidase following cold immobilization stress. J Natural Remedies 1(2): 144-146.

13. Feo DV (1992) Medicinal and magical plants in the Northern Peruvian Andes. Fitoterapia 63:417.

14. Zadra de, Adriana Alarco, Perú-El libro de las plantas mágicas (2000) 2nd Ed. Lima: Concytec 16.

15. Hasrat JA, De Bruyne T, De Backer JP, Vauquelin G, Vlietinck AJ (1997) Isoquinoline derivatives isolated from the fruit of Annona muricata as 5-HTergic 5HT1a receptor agonists in rats: unexploited antidpressive (lead) products. J Pharm Pharmacol 49(11): 1145-1149. 
16. Gbeassor M, Kedjagni AY, Koumaglo K, de Souza C, Agbo K (1990) In vitro antimalarial activity of six medicinal plants. Phytother Res 4(3): 115-117.

17. Ayensu ES (1978) Medicinal plants of the West Indies. Unpublished Manuscript 110.

18. Talyor L (2002) Technical Data Report for Graviola (Annona muricata). Sage Press Inc.

19. Ye Q, Alfonso D, Evert D, McLaughlin JL (1996) Longifolicin, longicoricin and gigantetroneninone, three novel bioactive monotetrahydrofuran annonaceous acetogenins from Asimina longifolia (Annonaceae). Bioorg Med Chem. 4(4): 537-545.

20. Chang FR, Wu YC (2001) Novel cytotoxic annonaceous acetogenins from Annona muricata. J Nat Prod 64(7): 925-931.

21. Chang FR, Liaw CC, Lin CY, Chou CJ, Chiu HF, et al. (2003) New adjacent bis-tetrahydrofuran annonaceous acetogenins from Annona muricata. Planta Med 69(3): 241-246.
22. Moghadamtousi SZ, Fadaeinasab M, Nikzad S, Mohan G, Ali HM, et al. (2015) Annona muricata (Annonaceae): A Review of Its Traditional Uses, Isolated Acetogenins and Biological Activities. Int J Mol 16(7): 15625-15658.

23. Banerjee A, Sengupta A, Maji B, Nandi A, Pal S, et al. (2017) Possible Cytotoxic Activity of Annona muricata Leaves in Huh-7 Human Liver Cancer Cells. Hepatol Pancreat Sci 1(1): 104.

24. Banerjee A, Das D, Maji BK and Mukherjee S (2017) Potential Chemo Preventive Bioactive Compound Acetogenins in Liver Cancer. J Mol Histol Med Physiol 2: 101 .

25. Amit Swarnakar (2014) literary approach to Annona muricata and its role in cancer- A review. Int J of Res in Pharmacology \& Pharmacotherapeutics 3(4): 320327. 